\author{
JURNAL \\ DISRUPSI BISNIS \\ ISSN $2621-797 \mathrm{X}$ \\ Jurnal Disrupsi Bisnis, Vol. 3, No. 2, Juli 2020 (108 - 119) \\ Prodi Manajemen Fakultas Ekonomi Universitas Pamulang
}

\title{
PENGARUH KUALITAS PELAYANAN DAN KUALITAS PRODUK TERHADAP MINAT BELI KONSUMEN PADA PT NIRWANA GEMILANG PROPERTY
}

\author{
Nurmin Arianto dan Sabta Ad Difa \\ Fakultas Ekonomi, Universitas Pamulang \\ dosen01118@unpam.ac.id
}

\begin{abstract}
ABSTRAK
Penelitian ini bertujuan untuk mengetahui pengaruh kualitas pelayanan dan kualitas produk terhadap minat beli konsumen pada PT Nirwana Gemilang Property. Metode penelitian yang digunakan adalah pendekatan kuantitatif deskriptif. Populasi pada penelitian ini adalah konsumen yang berkunjung ke kantor pemasaran PT Nirwana Gemilang Property dan untuk pengambilan sampel menggunakan rumus slovin dengan jumha responden berjumlah 86. Analisis yang dikunakan adalah analisis regresi linier berganda, koefisien determinasi serta pengujian hipotesis dengan uji $t$ dan uji f. Hasil penelitian ini menunjukan bahwa terdpaat pengaruh yang positif dan signifikan baik secara parsial ataupun simultan antara kualitas pelayanan dan kualitas produk terhadap minat beli.
\end{abstract}

Kata Kunci : Kualitas Pelayanan, Kualitas Produk, dan Minat Beli

\section{ABSTRACT}

This study aims to determine the effect of service quality and product quality on consumer buying interest at PT Nirwana Gemilang Property.The research method used is descriptive quantitative approach. The population in this study were consumers who visited the marketing office of PT Nirwana Gemilang Property and for taking samples using the Slovin formula with 86 respondents. The analysis used was multiple linear regression analysis, coefficient of determination and hypothesis testing with $t$ test and $f$ test.The results of this study indicate that there is a positive and significant influence either partially or simultaneously between service quality and product quality on buying interest. Keywords: Service Quality, Product Quality, and Purchase Interest

\section{PENDAHULUAN}

\section{Latar Belakang}

Perumahan adalah salah satu contohnya merupakan salah satu kebutuhan primer yang harus dimiliki oleh setiap manusia. Bagi mereka yang sudah menikah, mempunyai rumah sendiri adalah sesuatu yang diimpikan. Potensi inilah yang sepertinya dilihat oleh para developer perumahan sehingga mereka saling bersaing satu dengan lainnya dalam pemasaran produk perumahannya. Kualitas pelayanan meliputi pelayanan langsung dari marketing di lapangan, fleksibilitas pengembang, serta cara pembayaran seperti kredit kepemilikan rumah yang mudah dan fleksible adalah hal dalam pelayanan di bidang properti khususnya perumahan yang dapat mempengaruhi minat pada produk properti untuk memenuhi kepuasan konsumen. PT Nirwana Gemilang 
Property sebagai Agency Properti yang bekerja sama dengan developer dalam hal pemasaran produk property yang di kembangkan oleh developer tersebut secara exclusive maupun open listing. PT Nirwana Gemilang Property yang notabane nya memasarkan produk properti milik developer di sekitaran wilayah Jabodetabek. Namun dari segi pelayanan memang persaingan antar perusahaan semakin sengit, untuk menyikapi persaingan tersebut, beragam upaya dilakukan demi mendapatkan konsumen yang setia, seperti melalui cara pelayanan dengan tutur kata yang sopan lemah dan lembut dan memberikan konsumen dengan hadiah atau promo diskon di pameran maupun event - event tertentu dengan memanjakan konsumen agar perusahan selalu mudah diingat dan dicari oleh para konsumen yang setia karena kesan pertama dari pelayanan tersebut, yang dimaksud konsumen setia disini adalah jika konsumen yang sudah tertarik dengan produk properti yang kita pasarkan, mereka akan memberitahukan informasi kepada saudara, kerabat kerja dan kawan - kawannya untuk membeli produk properti yang kita pasarkan.

\section{Tabel 1 Service Marketing Project \\ PT. Nirwana Gemilang Property}

\begin{tabular}{|l|c|l|l|c|}
\hline $\begin{array}{c}\text { Lokasi } \\
\text { Perumahan }\end{array}$ & $\begin{array}{c}\text { Jumlah } \\
\text { complain }\end{array}$ & \multicolumn{1}{|c|}{$\begin{array}{c}\text { Product } \\
\text { knowledge }\end{array}$} & $\begin{array}{c}\text { Mutu } \\
\text { pelayanan }\end{array}$ & $\begin{array}{c}\text { Nilai } \\
\text { Pelayanan }\end{array}$ \\
\hline $\begin{array}{l}\text { Witanaharja } \\
\text { Estate }\end{array}$ & 43 & $\begin{array}{l}\text { Cukup menguasai } \\
\text { perbankan, tapi } \\
\text { kurang } \\
\text { menguasai } \\
\text { perihal Amdal } \\
\text { Lingkungan }\end{array}$ & $\begin{array}{l}\text { Marketing } \\
\text { kurang jelas } \\
\text { saat } \\
\text { memberikan } \\
\text { informasi }\end{array}$ & Kurang Baik \\
\hline TreVista Serua & 51 & $\begin{array}{l}\text { Kurang } \\
\text { menguasai } \\
\text { perihal legalitas }\end{array}$ & $\begin{array}{l}\text { Marketing } \\
\text { kurang loyal } \\
\text { kepada } \\
\text { konsumen }\end{array}$ & Kurang Baik \\
\hline Aphrodite & 39 & $\begin{array}{l}\text { Kurang } \\
\text { menguasai } \\
\text { perbankan }\end{array}$ & $\begin{array}{l}\text { Marketing } \\
\text { kurang } \\
\text { ramah }\end{array}$ & Kurang Baik \\
\hline
\end{tabular}

Sumber: Analisis pelayanan marketing project dilihat dari trafic konsumen tahun 2019 PT.

Nirwana Gemilang Property.

Kualitas pelayanan dan service dari marketing yang kurang memuaskan. Pelayanan dan fasilitas pembiayaan kredit yang disediakan oleh bank rekanan kurang memuaskan. Keluhan lain yang berhubungan dengan masalah properti adalah keluhan dari para konsumen terhadap Developer yang mengingkari janji yang diberikan pada saat promosi produk perumahan.

Seiring dengan gaya hidup masyarakat modern yang dinamis lebih cenderung membutuhkan rumah dengan berbagai fasilitas seperti sarana olahraga (club house), taman, keamanan, rekreasi di dalam satu kawasan dengan sistem satu pintu akses keluar masuk atau disebut One Gate Security System. dominan dari konsumen yang tengah mencari hunian untuk tinggal maupun investasi dari kalangan menengah ke bawah, yang rata-rata membeli rumah pertama mereka, tidak hanya harga yang menjadi pertimbangan utama. Tapi kualitas produk yang utama menjadi pertimbangan konsumen. Yang dimaksud kualitas produk menurut Mowen, (2012:16) Kualitas produk merupakan proses evaluasi secara keseluruhan kepada pelanggan atas perbaikan kinerja suatu produk. Apa yang menjadi pertimbangan bagi konsumen dalam memutuskan untuk membeli properti: Lokasi, Tema Arsitektur (Desain), 
Kualitas Spesifikasi Bangunan, Skema pembayaran, dan Harga. Keluhan diantaranya yakni kualitas bangunan tidak sesuai keinginan dan kebutuhan konsumen, material dan layout bangunan mempengaruhi minat beli konsumen, serta minimnya prasarana dalam perumahan, hingga kualitas produk perumahan yang mengecewakan dan tidak sesuai harapan yang sering diajukan konsumen kepada para developer.

Tabel 2 Spesifikasi Produk

Project Handle: PT. Nirwana Gemilang Property

Sumber: Analisis kualitas produk project property tahun 2019 PT. Nirwana Gemilang.

\begin{tabular}{|c|c|c|c|c|}
\hline $\begin{array}{l}\text { Nama } \\
\text { Perumahan }\end{array}$ & $\begin{array}{c}\text { Spesifikasi } \\
\text { Material }\end{array}$ & $\begin{array}{l}\text { Total } \\
\text { Unit }\end{array}$ & Lokasi & Harga \\
\hline $\begin{array}{l}\text { Witanaharja } \\
\text { Estate }\end{array}$ & $\begin{array}{l}\text { Dinding bata merah, } \\
\text { lantai granito, kusen } \\
\text { alumunium, plafond } \\
\text { gypsum dsb. }\end{array}$ & 8 & Pamulang & 800 jutaan \\
\hline Aphrodite & $\begin{array}{lr}\text { Dinding } & \text { hebel, } \\
\text { lantai } & \text { keramik, } \\
\text { kusen } & \text { alumunium, } \\
\text { plafond } & \text { gypsum } \\
\text { dsb. } & \end{array}$ & 9 & Pamulang & 500 jutaan \\
\hline TreVista Serua & $\begin{array}{l}\text { Dinding bata merah, } \\
\text { lantai granito, kusen } \\
\text { alumunium, plafond } \\
\text { gypsum dsb. }\end{array}$ & 45 & Serua Depok & $700 \quad$ T \\
\hline
\end{tabular}

Menurut sebagian konsumen yang survey menyatakan bahwa kualitas bangunan tidak sesuai keinginan dan kebutuhan konsumen. Material dan layout bangunan mempengaruhi minat beli konsumen.

Dalam pelayanan pun PT Nirwana Gemilang Property memiliki beberapa marketing dalam setiap project nya yang memasarkan dan memberi pelayanan langsung kepada konsumen di kantor pemasaran. Sehingga kualitas pelayanan dan kualitas produk memberi dampak yang mempengaruhi minat beli konsumen.

Jadi pengalaman yang dianggap bernilai merupakan faktor yang turut membuat minat pada diri individu. Pengalaman memberikan motivasi serta kekuatan pada diri individu untuk melakukan sesuatu. Menurut Pramono (2012 : 136), "Minat beli konsumen adalah tahap dimana konsumen membentuk pilihan mereka diantara beberapa merek yang tergabung dalam perangkat pilihan, kemudian pada akhirnya melakukan suatu pembelian pada suatu alternatif yang paling disukainya atau proses yang dilalui konsumen untuk membeli suatu barang atau jasa yang didasari oleh bermacam pertimbangan"

Dari pernyataan diatas berikut pertimbangan akan minat beli akan mempengaruhi penjualan, sehingga dari beberapa tahun ini penjualan di PT Nirwana Gemilang Property masih belum mencapai target. berikut ini adalah Tabel data penjualan pada produk property yang dipasarkan oleh PT Nirwana Gemilang Property. 
Tabel 3

Target Tahunan PT. Nirwana Gemilang Property Periode 2017-2019

\begin{tabular}{|c|c|c|c|c|c|c|c|c|c|c|c|}
\hline Tahun 2016 & Penjualan & Target & Realisasi & Tahun 2017 & Penjualan & Target & Realisasi & Tahun 2018 & Penjualan & Target & Realisasi \\
\hline Januari & 1.509 .000 .000 & 3.000 .000 .000 & $50 \%$ & Januari & 1.908 .000 .000 & 3.000 .000 .000 & $64 \%$ & Januari & 875.600 .000 & 3.000 .000 .000 & $29 \%$ \\
\hline Februari & 76.420 .000 & 3.000 .000 .000 & $39 \%$ & ruari & 37.000 .000 & 3.000 .000 .000 & $41 \%$ & Februari & 1.184 .200 .000 & 3.000 .000 .000 & $39 \%$ \\
\hline Maret & 1.750 .000 .000 & 3.000 .000 .000 & $58 \%$ & taret & 864.000 .000 & 3.000 .000 .000 & $62 \%$ & Maret & 1.750 .000 .000 & 3.000 .000 .000 & $58 \%$ \\
\hline April & 982.800 .000 & 2.500 .000 .000 & $39 \%$ & April & 808.200 .000 & 2.500 .000 .000 & $32 \%$ & April & 982.800 .000 & 2.500 .000 .000 & $39 \%$ \\
\hline Mei & 911.380 .000 & 2.500 .000 .000 & $36 \%$ & Mei & 954.960 .000 & 2.500 .000 .000 & $38 \%$ & Mei & 1.128 .000 .000 & 2.500 .000 .000 & $45 \%$ \\
\hline Juni & 1.125 .760 .000 & 2.500 .000 .000 & $45 \%$ & Juni & 2.176 .550 .000 & 2.500 .000 .000 & $87 \%$ & Juni & 1.125 .760 .000 & 2.500 .000 .000 & $45 \%$ \\
\hline Juli & 1.156 .000 .000 & 2.000 .000 .000 & $58 \%$ & Juli & 1.156 .000 .000 & 2.000 .000 .000 & $58 \%$ & Juli & 2.156 .780 .000 & 2.000 .000 .000 & $108 \%$ \\
\hline Agustus & 1.887 .310 .000 & 2.000 .000 .000 & $94 \%$ & Agustus & 1.165 .900 .000 & 2.000 .000 .000 & $58 \%$ & Agustus & 1.521 .800 .000 & 2.000 .000 .000 & $76 \%$ \\
\hline September & 1.853 .000 .000 & 2.000 .000 .000 & $93 \%$ & September & 1.853 .000 .000 & 2.000 .000 .000 & $93 \%$ & September & 2.053 .000 .000 & 2.000 .000 .000 & $103 \%$ \\
\hline Oktober & 1.567 .200 .000 & 3.500 .000 .000 & $45 \%$ & Oktober & 3.267 .900 .000 & 3.500 .000 .000 & $93 \%$ & Oktober & 1.567 .200 .000 & 3.500 .000 .000 & $45 \%$ \\
\hline November & 1.042 .700 .000 & 3.500 .000 .000 & $30 \%$ & Nopember & 986.940 .000 & 3.500 .000 .000 & $28 \%$ & November & 1.412 .300 .000 & 3.500 .000 .000 & $40 \%$ \\
\hline Desember & 2.677 .000 .000 & 3.500 .000 .000 & $76 \%$ & December & 2.559 .000 .000 & 3.500 .000 .000 & $73 \%$ & Desember & 2.678 .820 .000 & 3.500 .000 .000 & $77 \%$ \\
\hline Total & 17.638 .570 .000 & 33.000 .000 .000 & $53 \%$ & Total & 19.937 .450 .000 & 3.000 .000 .000 & $60 \%$ & Total & 18.436 .260 .000 & 33.000 .000 .000 & $56 \%$ \\
\hline
\end{tabular}

\section{Sumber: Laporan penjualan Tahun 2016-2018 PT. Nirwana Gemilang Property}

Dari tabel berikut dapat disimpulkan bahwa setiap tahunnya tingkat terjadi pembelian sangat rendah ketika disaring data dari konsumen yang survey dan berminat. Sehingga mempengaruhi minat beli konsumen serta penjualan di PT Nirwana Gemilang Property.

Dari tabel diatas menunjukkan bahwa faktor kualitas pelayanan dan kualitas produk merupakan faktor yang menjadi pertimbangan konsumen dan mempengaruhi minat beli konsumen. Oleh karena itu, pemahaman mengenai faktor-faktor yang mempengaruhi minat beli konsumen yang meliputi kualitas pelayanan dan kualitas produk perlu untuk diketahui oleh PT Nirwana Gemilang Property agar dapat memenuhi kebutuhan konsumen sebaik mungkin kedepannya.

\section{Rumusan Masalah}

Berdasarkan latar belakang di atas, maka diangkatlah rumusan permasalahan:

a. Bagaimana pengaruh kualitas pelayanan terhadap minat beli pada PT. Nirwana Gemilang Property?

b. Bagaimana pengaruh kualitas produk terhadap minat beli pada PT. Nirwana Gemilang Property?

c. Bagaimana pengaruh kualitas pelayanan dan kualitas produk terhadap minat beli pada PT. Nirwana Gemilang Property?

\section{Tujuan Penelitian}

Adapun tujuan penelitian antara lain :

a. Untuk mengetahui bagaimana pengaruh kualitas pelayanan di PT Nirwana Gemilang Property terhadap minat beli konsumen.

b. Untuk mengetahui bagaimana pengaruh kualitas produk terhadap minat beli konsumen.

c. Untuk mengetahui bagaimana pengaruh kualitas pelayanan dan kualitas produk terhadap minat beli konsumen.

\section{TINJAUAN PUSTAKA}

\section{Landasan Teori}

\section{a. Kualitas Pelayanan}

1) Pengertian Kualitas Pelayanan

Menurut Fandy Tjiptono (2014 : 268) Kualitas pelayanan berfokus pada upaya pemenuhan kebutuhan dan keinginan konsumen serta penetapan penyampainya untuk mengimbangi harapan konsumen. 
Definisi lain kualitas pelayanan menurut Wyckof dalam Lovelock yang dikutip oleh Fandy Tjiptono (2012:270) merupakan tingkat keunggulan (excellence) yang diharapkan dan pengendalian atas keunggulan tersebut untuk memenuhi keinginan pelanggan.

2) Indikator Kuaitas Pelayanan

Menurut Zeithaml et al (2013:42) terdapat indikator - indikator kualitas layanan yaitu : Bukti Fisik (Tangibles), Empati (Emphaty), Keandalan (Reliability), Daya tanggap (Responsiveness), Jaminan (Assurance).

\section{b. Kualitas Produk}

1) Pengertin Kualitas Produk

Menurut Mowen (2012:16) Kualitas produk merupakan proses evaluasi secara keseluruhan kepada konsumen atas perbaikan kinerja suatu produk.

Adapun Menurut Philip kotler (2012:143) Kualitas produk adalah totalitas fitur dan karakteristik produk atau jasa yang bergantung pada kemampuanya untuk memuaskan kebutuhan yang dinyatakan atau tersirat.

2) Indikator Kualitas Produk

Berdasarkan pendapat David Garvin (2016:27), untuk menentukan dimensi kualitas produk dapat melalui delapan indikator yaitu Kinerja (performance), Fitur produk (features), Kehandalan (reability), Kesesuaian (conformance), Daya tahan (durability), Kemampuan memperbaiki (servieceability), Keindahan/estetika (asthetics), Kualitas yang dipersepsikan (perceived quality).

\section{c. Minat Beli}

1) Pengertian Minat

Menurut Pramono (2012: 136), Minat beli konsumen adalah tahap dimana konsumen membentuk pilihan mereka diantara beberapa merek yang tergabung dalam perangkat pilihan, kemudian pada akhirnya melakukan suatu pembelian pada suatu alternatif yang paling disukainya atau proses yang dilalui konsumen untuk membeli suatu barang atau jasa yang didasari oleh bermacam pertimbangan. Menurut Durianto (2013), Minat Beli adalah keinginan untuk memiliki produk, minat beli akan timbul apabila seseorang konsumen sudah terpengaruh terhadap mutu dan kualitas dari suatu produk, informasi seputar produk.

2) Indikator Minat

Menurut Schiffman dan Kanuk (2010:470). komponen komponen indikator minat beli yakni: Tertarik pada informasi mengenai produk, Mempertimbangkan untuk membeli, Tertarik untuk mencoba, Ingin mengetahui produk, Jadi ingin memiliki produk

\section{Hipotesis}

$\mathrm{H}_{1}$ : Diduga variabel kualitas pelayanan berpengaruh terhadap minat beli konsumenpada PT Nirwana Gemilang Property.

$\mathrm{H}_{2}$ : Diduga variabel kualitas produk berpengaruh terhadap minat beli konsumen pada PT Nirwana Gemilang Property.

$\mathrm{H}_{3}$ :Diduga variabel kualitas pelayanan dan kualitas produk secara simultan berpengaruh terhadap minat beli konsumen pada PT Nirwana Gemilang Property.

\section{Kerangka Pemikiran}

Menurut Uma Sekaran dalam Sugiyono (2011:60) mengemukakan bahwa Kerangka berpikir merupakan model konseptual tentang bagaimana teori berhubungan dengan 
berbagai faktor yang telah diidentifikasi sebagai hal yang penting jadi dengan demikian maka kerangka berpikir adalah sebuah pemahaman yang melandasi pemahaman-pemahaman yang lainnya, sebuah pemahaman yang paling mendasar dan menjadi pondasi bagi setiap pemikiran atau suatu bentuk proses dari keseluruhan dari penelitian vang akan dilakukan.

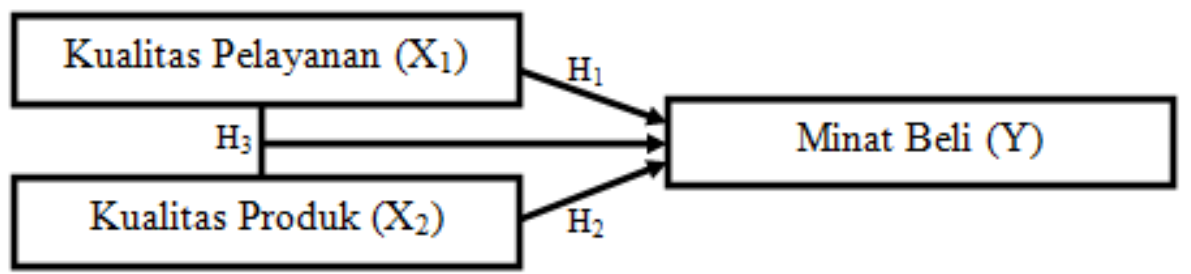

\section{METODE PENELITIAN}

\section{Populasi Dan Sample}

Adapun populasi dalam penelitian ini adalah konsumen yang membeli dan mengeluh mengenai kualitas pelayanan dan kualitas produk properti PT Nirwana Gemilang Property dari tahun 2017 sampai dengan 2019 yaitu sebanyak 595 konsumen dan Teknik sampling yang digunakan dalam penelitian ini adalah Probability Sampling adalah teknik pengambilan sampel yang memberikan peluang yang sama bagi setiap unsur (anggota) populasi untuk dipilih menjadi anggota sampel (Sugiyono, 2012 : 92). Dengan jenis Simple Random Sampling adalah pengambilan anggota sampel dari populasi yang dilakukan secara acak tanpa memperhatikan strata yang ada dalam populasi itu (Sugiyono, 2012:93). Untuk mendapatkan sampel yang representatif maka penulis mengambil beberapa sampel yang memiliki peluang yang sama dengan menggunakan rumus Slovin (Syofian Siregar, 2010:149) dengan tingkat error sebesar 10\% maka di peroleh 86 Responden.

\section{Teknik Pengumpulun Data}

Dalam penelitian ini penulis meggunakan Observasi yang dilakukan peneliti dalam proses pengamatan merupakan observasi non-partisipan karena peneliti tidak terlibat dan hanya sebagai pengamat independen. Dan apabila dilihat dari instrumennya yaitu masuk ke kategori observasi terstruktur sebab peneliti telah merancang secara sistematis tentang apa yang akan diamati, kapan dan dimana tempatnya. Dan teknik wawancara yang digunakan oleh peneliti adalah wawancara tidak terstruktur karena tidak menggunakan pedoman dan biasanya dilakukan pada awal pra penelitian untuk menanyakan keterkaitan data dan permasalahan yang akan diteliti. Selaian itu juga dalam penelitian ini menggunakan kuisioner tertutup dimana alternatif jawaban telah tersedia dan responden cukup memberikan tanda pada jawaban yang dipilih.

\section{Uji Istrumen}

Dlaam penelitia ini peneliti menggunakan uji Instrumen yaitu uji Validitas dan Uji Relibilitas dimana membandingkan nilai $r$ hitung atau $r$ ca dengan $r$ tabel. Dimana nilai $r$ tabel untuk validitas ialah 0,300 sesuai dengan Teori Sugiyono (2017:182) sedangkan $r$ tabel untuk Uji Relibilitas ialah 0,600 dengan menggunakan Teori Sugiyono (2017:184).

\section{Uji Asumsi Klasik}

Setelah data yang diperoleh Valid dan Relibael maka peneliti menguji data tersebut menggunakan uji asumsi klasik yang terdiri dari Uji Normalitas,Uji Multikolinearitas, Uji Heteroskedastiisitas.

\section{Analisis Regresi Linear Bergaganda}

Persamaan umum regresi berganda menurut Sugiyono (2010:277) adalah:

$y=\alpha+\beta 1 \times 1+\beta 2 \times 2+\varepsilon$ 
Setelah melakukan analisis Regresi Berganda maka penulis menguji Hipotesis baik secara parsila ataupun simultan.

\section{HASIL DAN PEMBAHASAN}

\section{Uji Instrumen Penelitian}

\section{a. Uji Validitas}

Tabel 4

Hasil Uji Validitas

\begin{tabular}{|c|c|c|c|c|c|}
\hline \multirow{2}{*}{ No Kuisioner } & \multicolumn{3}{|c|}{ r Hitung } & \multirow{2}{*}{ R tabel } & \multirow{2}{*}{ Ket } \\
\cline { 2 - 4 } & $\begin{array}{c}\text { Kualitas } \\
\text { Pelayanan }\end{array}$ & $\begin{array}{c}\text { Kualitas } \\
\text { Produk }\end{array}$ & Minat Beli & & \\
\hline 1 & 0,423 & 0,453 & 0,467 & 0,300 & Valid \\
\hline 2 & 0,460 & 0,320 & 0,486 & 0,300 & Valid \\
\hline 3 & 0,467 & 0,307 & 0,410 & 0,300 & Valid \\
\hline 4 & 0,641 & 0,660 & 0,580 & 0,300 & Valid \\
\hline 5 & 0,423 & 0,343 & 0,414 & 0,300 & Valid \\
\hline 6 & 0,464 & 0,672 & 0,495 & 0,300 & Valid \\
\hline 7 & 0,640 & 0,526 & 0,418 & 0,300 & Valid \\
\hline 8 & 0,460 & 0,327 & 0,442 & 0,300 & Valid \\
\hline 9 & 0,467 & 0,555 & 0,406 & 0,300 & Valid \\
\hline 10 & 0,647 & 0,312 & 0,609 & 0,300 & Valid \\
\hline 11 & - & 0,359 & - & 0,300 & Valid \\
\hline 12 & - & 0,585 & - & 0,300 & Valid \\
\hline 13 & - & 0,311 & - & 0,300 & Valid \\
\hline 14 & - & 0,312 & - & 0,300 & Valid \\
\hline 15 & - & 0,552 & - & 0,300 & Valid \\
\hline 16 & - & 0,304 & - & 0,300 & Valid \\
\hline
\end{tabular}

Berdasarkan tabel diatas maka dapat disimpulkan semua variabel dinyatakan valid, karena $r_{\text {hitung }}>r_{\text {tabe, }}$ dan hal ini sejalan dengan teori Sugiyono (2017:182).

b. Uji Reliabilitas

Tabel 5

\section{Uji Reliabilitas}

\section{Rangkuman Analisa Uji Reliabilitas}

\begin{tabular}{|c|c|c|c|}
\hline Variabel & Alpha Cronbacch & Syarat & Keterangan \\
\hline Kualitas Pelayanan $\left(\mathrm{X}_{1}\right)$ & 0,677 & 0,60 & Reliabel \\
\hline Kualitas Produk $\left(\mathrm{X}_{2}\right)$ & 0,710 & 0,60 & Reliabel \\
\hline Minat Beli $(\mathrm{Y})$ & 0,609 & 0,60 & Reliabel \\
\hline
\end{tabular}

Berdasarkan tabel diatas dapat disimpulkan bahwa seluruh pernyataan dalam kuisioner dikatakan reliabel dan baik sehingga dapat digunakan dalam penelitian ini, hal ini sejalan dengan teori Sugiyono (2017:184).

\section{Uji Asumsi Klasik}

a. Uji Normalitas

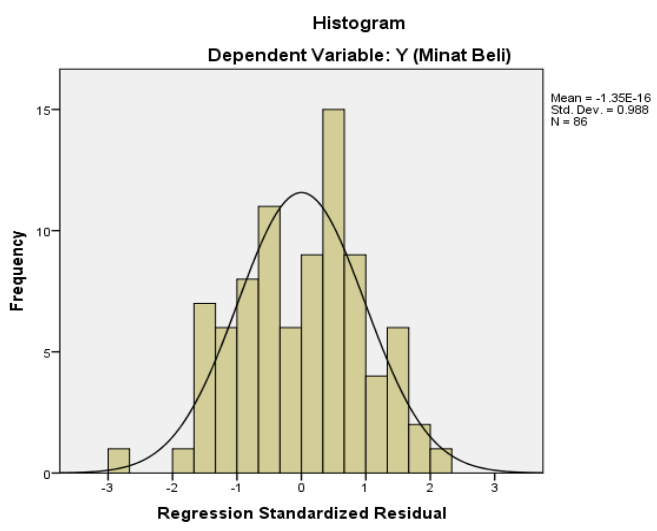

Gambar 1. Histogram

Pada grafik histogram terlihat pola distribusi yang melenceng kekanan yang arti nya data tersebut berdistribusi normal.

b. Uji Multikolinearitas 


\section{Tabel 6 \\ Hasil output SPSS uji Multikoliniearitas}

\begin{tabular}{|l|r|r|}
\hline \multicolumn{3}{|c|}{ Coefficients $^{\mathrm{a}}$} \\
\hline \multicolumn{3}{|c|}{ Collinearity Statistics } \\
\hline Variabel & Tolerance & \multicolumn{1}{c|}{ VIF } \\
& & \\
\hline $\mathrm{X} 1$ & 0.533 & 1.875 \\
\hline $\mathrm{X} 2$ & 0.533 & 1.875 \\
\hline
\end{tabular}

Dari data tabel di atas maka diperoleh nilai: Tolerance Value Kualitas Pelayanan 0,533 > 0,1 dan VIF Kualitas Pelayanan 1,875 < 10,0 sertan nilai Tolerance Value Kualitas Produk 0,533 > 0,1 dan VIF Kualitas Produk 1,875 < 10,0.Maka bebas dari adanya multikolinearitas dan semua variabel bebas yang dipakai dalam penelitian ini lolos gelaja multikolinearitas.

c. Heteroskedastisitas

Berikut hasil pengolahan menggunakan program SPSS.

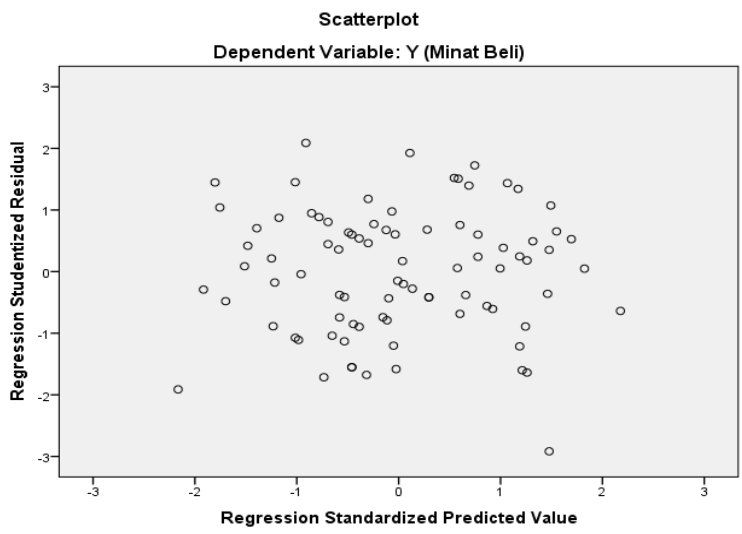

\section{Gambar 2}

Grafik Scatter plot

Scatterplot terlihat bahwa titik-titik menyebar secara acak serta tersebar baik di atas maupun dibawah angka nol pada sumbu Y. Hal ini dapat disimpulkan tidak terjadi heteroskedastisitas pada model regresi ini.

\section{c. Analisis Deskriptif}

a. Variabel Kualitas Pelayanan

Dari hasil anaslisi deskriptif diperoleh nilai rata-rata yaitu 3,83 atau di berada di kategori skala $(3,41-4,20$ : Tinggi) dimana tanggapan responden terhadap variabel kualitas pelayanan $\left(\mathrm{x}_{1}\right)$ memiliki kategori skala Tinggi atau Baik, dilihat dari skor tertinggi 3,88 yaitu pada indikator "Kehandalan" dimana marketing mampu mempresentasikan produk dengan detail sehingga dimengerti oleh konsumen dan mampu menjawab pertanyaan dengan baik sehingga banyak responden yang memilih produk PT Nirwana Gemilang Property dikarenakan kemampuan marketing dalam menguasai dan mampu menjelaskan dengan baik produk sehingga mudah dipahami oleh konsumen.

Disamping itu pihak perusahaan harus lebih meningkatkan kualitas pelayanan dari indikator "Respon marketing" karena nilai rata rata pada indikator ini yaitu 3,83 yang dimana marketing harus siap merespon permintaan konsumen dan tanggap terhadap masalah maka dari itu sebaiknya marketing diberikan pelatihan atau arahan khusus pada point ini sehingga dapat meningkatkan kualitas pelayanan. 
b. Variabel Kualitas Produk

Dari hasil anaslisi deskriptif diperoleh nilai rata-rata yaitu 3,95 atau di berada di kategori skala $(3,41-4,20$ : Tinggi) dimana tanggapan responden terhadap variabel kualitas produk $\left(\mathrm{x}_{2}\right)$ memiliki kategori skala tinggi atau baik, dilihat dari skor tertinggi 4,12 yaitu pada indikator "Estetika" dimana perumahan PT Nirwana Gemilang Property memberikan reputasi yang baik dan konsumen merasa PT Nirwana Gemilang Property bisa dipercaya dalam menjamin dan memenuhi kebutuhan konsumen akan hunian yang asri dan baik. hal ini membuktikan bahwa produk yang di miliki oleh PT Nirwana Gemilang Property memang memberikan reputasi yang baik, baik untuk konsumen maupun untuk lingkungan sekitar.

Disamping itu pihak perusahaan harus lebih meningkatkan kualitas produk dari indikator "Ketahanan" dimana perumahan miliki PT Nirwana Gemilang Property dapat dihuni lebih dari 15 tahun dan konsumen merasa bahan material yang digunakan dalam pembangunan seperti bata hebel, granit, alumunium, gypsum,rangka baja ringan,dll sudah cukup membuat bangunan kokoh dan tahan lama saat dihuni" dimana diperoleh skor terendah 3,87. dengan arti lain PT Nirwana Gemilang Property harus meningkatkan kualitas pada indikator berikut, supaya dapat meningkatkan minat beli konsumen.

c. Minat Beli

Dari hasil anaslisi deskriptif diperoleh nilai rata-rata yaitu 3,94 atau berada di kategori skala $(3,41-4,20$ : Tinggi) dimana tanggapan responden terhadap variabel minat beli (Y) memiliki kategori skala tinggi atau baik, dilihat dari skor tertinggi 4,03 yaitu pada indikator "Jadi ingin memiliki produk" dimana konsumen berminat membeli karena yakin pada kualitas bangunan perumahan milik PT Nirwana Gemilang Property dan karena puas terhadap pelayanan dan informasi yang diberikan. hal ini membuktikan bahwa persepsi kualitas produk yang bagus dan pelayanan yang baik mempengaruhi minat beli konsumen.

Disamping itu untuk meningkatkan minat beli pihak perusahaan harus lebih meningkatkan dari indikator " Mempertimbangkan untuk membeli" dimana Dengan adanya desain dan layout rumah yang dibuat PT Nirwana Gemilang Property dapat meningkatkan minat konsumen untuk membeli dan kualitas pelayanan dan kualitas produk juga menjadi bahan pertimbangan konsumen untuk membeli produk dimana diperoleh skor terendah 3,87. berdasarkan skor tersebut PT Nirwana Gemilang Property harus meningkatkan daya tarik dari indikator tersebut untuk meningkatkan minat beli konsumen.

\section{d. Analisis Kuantitatif}

1. Analisis Regresi Berganda

Berdasarkan uji dengan program SPSS diperoleh hasil regresi berganda seperti terangkum pada tabel berikut :

Tabel 7

Hasil Uji Regresi Linear Berganda

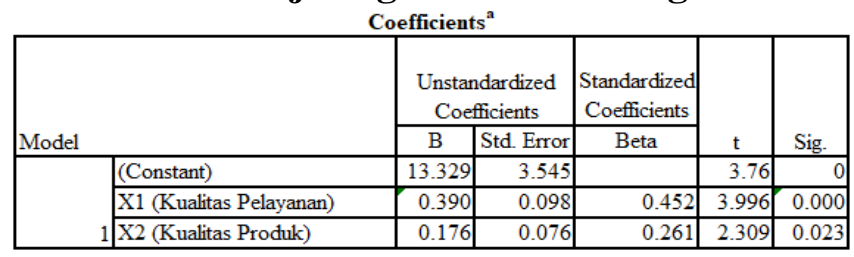

Berdasarkan tabel d1 atas diperoleh persamaan regresı berganda sebagai berikut:

$$
Y=13,329+0,390 X_{1}+0,176 X_{2}+e
$$


Persamaan regresi tersebut mempunyai makna sebagai berikut:

a) Konstanta sebesar 13,329 menyatakan bahwa tanpa ada variabel kualitas pelayanan $\left(x_{1}\right)$ dan kualitas produk $\left(x_{2}\right)$ maka minat beli $(\mathrm{y})$ tetap terbentuk sebesar 13,329 atau jika nilai kualitas pelayanan $\left(x_{1}\right)$,dan kualitas produk $\left(x_{2}\right)$ nilainya $=0$ maka minat beli tetap memiliki nilai $=13,329$. Yang artinya konsumen akan tetap membeli produk tersebut meskipun kualitas pelayanan dan kualitas produk yang diberikan masih kurang, karena pada dasarnya konsumen membutuhkan produk tersebut untuk memenuhi kebutuhanya.

b) Variabel kualitas pelayanan $\left(x_{1}\right)$ berpengaruh positif terhadap minat beli $(\mathrm{y})$ dengan nilai koefisien sebesar 0,390. Artinya jika variabel kualitas pelayanan $\left(x_{1}\right)$ meningkat satu-satuan dengan asumsi bahwa variabel kualitas produk $\left(x_{2}\right)$, tetap, maka minat beli (y) akan meningkat sebesar 0,390.

c) Variabel kualitas produk $\left(x_{2}\right)$ berpengaruh positif terhadap minat beli (y) dengan nilai koefisien sebesar 0,176. Artinya jika variabel kualitas produk $\left(x_{2}\right)$ meningkat satu-satuan dengan asumsi bahwa variabel kualitas produk $\left(x_{1}\right)$ tetap, maka minat beli akan meningkat sebesar 0,176.

2. Korelasi dan Determinasi

Berdasarkan uji dengan program SPSS diperoleh hasil uji koefisien determinasi seperti terangkum pada tabel berikut :

\section{Tabel 8}

Hasil Uji Koefisien Determinasi

\begin{tabular}{|l|r|r|r|}
\hline Model & \multicolumn{1}{|c|}{$\mathrm{R}$} & R Square & $\begin{array}{c}\text { Adjusted R } \\
\text { Square }\end{array}$ \\
\hline 1 & $.659^{\mathrm{a}}$ & 0.434 & 0.42 \\
\hline
\end{tabular}
a. Predictors: (Constant), X2 (Kualitas Produk),
X1 (Kualitas Pelayanan)
b. Dependent Variable: Y (Minat Beli)

Jika dilita pada tabel tersebut maka Kualitas Pelayanan dan Kualitas Produk meiliki hubungan yang "Kuat" karena diperoleh Interval 0,60-0,799 berdasarkan Teori Sugiyono (2013:250), selain itu juga bahawa koefisien determinasi $(R$ Square) yang diperoleh sebesar 0,434 . Hal ini berarti $43,4 \%$ minat beli dapat dijelaskan oleh variabel $\mathrm{x}_{1}$ (kualitas pelayanan) dan $\mathrm{x}_{2}$ (kualitas produk) sedangkan sisanya 56,6\% minat beli dipengaruhi oleh variabel-variabel lain yang tidak diteliti.

3. Uji Hipotesis

a) Hipotesis Parsial

Berdasarkan tabel 10. Aka diperoleh nilai diperoleh $\mathrm{t}$ tabel 1,663 atau $=\operatorname{TINV}(0,05 ; 84)$ :

a. Pengaruh Kualitas Pelayanan $\left(\mathrm{x}_{1}\right)$ terhadap Minat Beli : Hasil uji parsial (uji t) antara kualitas pelayanan terhadap minat beli menunjukan nilai $\mathrm{t}$ hitung > t tabel $(3,996>1,663$ dan sig $<0,1(0,000<0,1)$ sehingga Ho di tolak dan $\mathrm{Ha}$ diterima yaitu "terdapat pengaruh kualitas pelayanan terhadap minat beli konsumen pada PT Nirwana Gemilang Property"

b. Pengaruh daya kualitas produk $\left(\mathrm{x}_{2}\right)$ terhadap minat beli : Hasil uji parsial (uji t) antara kualitas produk terhadap minat beli menunjukan nilai $\mathrm{t}$ hitung > t tabel 2,309 > 1,663) dani sig < 0,1 $(0,23<0,1)$ sehingga Ha diterima dan Ho ditolak yaitu "terdapat pengaruh kualitas produk terhadap minat beli konsumen pada PT Nirwana Gemilang Property" 
b) HipotesisSimultan

hasil uji $\mathrm{F}$ dapat diperoleh nilai $\mathrm{F}$ hitung $>\mathrm{F}$ tabel yaitu 31,799 > 2,37 dan nilai sig $<0,1$ atau $0,000<0,1$ " terdapat pengaruh kualitas pelayanan dan kualitas produk secara simultan terhadap minat beli konsumen pada PT Nirwana Gemilang Property".

\section{PENUTUP}

\section{Kesimpulan}

Berdasarkan rumusan masalah dan tujuan penelitian yang dipaparkan maka dapat diterik kesimpulan bahwa:

a. Berdasarkan rumusan masalah maka kualitas pelayanan memiliki pengaruh yang positif dan signifikan terhadap minat beli dimana diperoleh nilai $\mathrm{t}$ hitung $>\mathrm{t}$ tabel $(3,996>1,663)$ dan sig $<0,1(0,000<0,1)$.

b. Berdasarkan rumusan masalah maka kualitas produk memiliki pengaruh yang positif dan signifikan terhadap minat beli dimana diperoleh nilai $\mathrm{t}$ hitung $>\mathrm{t}$ tabel $(2,309>1,663)$ dan sig $<0,1(0,23<0,1)$

c. Berdasarkan rumusan masalah maka kualitas pelayanan dan kualitas produk memiliki pengaruh yang positif dan signifikan terhadap minat beli dimana diperolei nilai $\mathrm{F}$ hitung $>\mathrm{f}$ tabel yaitu $(31,799>2,37)$ dan nilai sig $<0,1$ atau

\section{Saran} $0,000<0,1$.

Dari hasil penelitian yang dijalankan dan hasil obervasi maka penulis memberikan saran bagi perusahaan:

a. PT Nirwana Gemilang Property harus lebih meningkatkan kualitas pelayanan dari indikator "Respon Marketing" dimana marketing harus siap merespon permintaan konsumen dan tanggap terhadap masalah maka dari itu sebaiknya marketing diberikan pelatihan atau arahan khusus pada point ini sehingga dapat meningkatkan kualitas pelayanan

b. PT Nirwana Gemilang Property harus lebih meningkatkan kualitas produk dari indikator "Ketahanan" PT Nirwana Gemilang Property harus meningkatkan kualitas pada indikator berikut, supaya dapat meningkatkan minat beli konsumen.

c. Untuk meningkatkan minat beli PT Nirwana Gemilang Property harus meningkatkan dari indikator " Mempertimbangkan untuk membeli" PT Nirwana Gemilang Property harus meningkatkan daya tarik dari indikator tersebut untuk meningkatkan minat beli konsumen.

\section{DAFTAR PUSTAKA}

AG.Suyono, S. S.. Pertimbangan Dalam Membeli Produk Barang Maupun Jasa. Jakarta: Intidayu Press.2012

Ajimat, A. (2020). Analisis Perbandingan Word Of Mouth Marketing dan Social Media Marketing dalam Menarik Minat Mahasiswa dalam Memilih Universitas (Studi Empiris pada Mahasiswa Universitas Pamulang). Jurnal Pemasaran Kompetitif, 3(2), 23-30.

Arianto, Nurmin. Pengaruh Kualitas Pelayanan, Harga Dan Kepuasan Terhadaployalitas Pasien (Studi Kasus Pada Pasien Rawat Jalan Rumah Sakit Premier Bintaro). Tangerang Selata: Jurnal JOM Universitas Terbuka. Vol 13, No 1, Hal 1-9.2017. Arianto, Nurmin. Pengaruh Promosi Dan Kualitas Pelayanan Terhadap Kepuasan Serta Berdampak Terhadap Loyalitas Pelanggan. Tangerang Selatan: Jurnal Kreatif. Vol 7, No 1, Hal 45-54. 2019. 
Arianto, Nurmin.Pengaruh Kualitas Pelayanan terhadap Kepuasan dan Loyalitas Pengunjung dalam Menggunakan Jasa Hotel Rizen Kedaton Bogor. Tangerang: Jurnal Pemasaran Kompetitif. Vol 1, No 2, Hal 83-101.2018.

Durianto, Darmadi. Strategi Menaklukan Pasar Melalui Riset Ekuitas dan Perilaku Merek (cet. ke-10). Jakarta: PT Gramedia Pustaka Utama.2013.

Fandy Tjiptono. Strategi Pemasaran, ed. 3, Yogyakarta: Andi.2012

Garvin, David A. Strategi Pemasaran.Yogyakarta: Andi.2016.

Kotler, Philip and Kevin Lane Keller. Marketing Management, Edisi 14. New Jersey: Prentice-Hall Published.2012.

Mowen, John C dan Minor, Micheal. Perilaku Konsumen dialih bahasakan oleh Dwi Kartika Yahya. Jakarta : Erlangga.2012

Schiffman, Leon.G. dan Leslie Lazar Kanuk. Perilaku Konsumen. Edisi Ke-7. Diterjemahkan oleh Zoelkifli Kasip. Jakarta: PT. Indeks.2007.

Sugiyono. Metode Penelitian Kuantitatif, Kualitatif dan R\&D. Bandung : Alfabeta.2011

Sugiyono. Metode Penelitian Kuantitatif, Kualitatif, dan R\&D. Bandung : Alfabeta.2017.

Tjiptono, Fandy. Pemasaran Jasa - Prinsip, Penerapan, dan Penelitia. Yogyakarta: Andi Offset.2014.

Zeithaml, V.A., M.J. Bitner, D.D. Gremler. Services Marketing: Integrating Customer Focus Across the Firm 6 thed. Boston: Mc.Graw-Hill.2013. 